\title{
Indigenous Mushroom Harvesting and Strategies among Rural Women in Ikwerre Kingdom, Rivers State, Nigeria
}

https://dx.doi.org/10.4314/jae.v23i1.9

\section{Elenwa, Caroline 0.}

Department of Agricultural Extension and Rural Development, Rivers State University, Port Harcourt, Nigeria

Email: carobinedo@yahoo.com; 07031616233

\section{Isife, Benjamin I.}

Department of Agricultural Extension and Rural Development, Rivers State University, Port Harcourt, Nigeria

Email: benisife@yahoo.com; 08036704977

\section{Nkoro, Faith 0.}

Department of Agricultural Extension and Rural Development, Rivers State University, Port Harcourt, Nigeria

Email: faithn@gmail.com:08123345711

\section{Abstract}

The study analysed indigenous mushroom harvesting and marketing among rural women in Ikwerre Kingdom of Rivers State, Nigeria. The data collected was through primary source, extracted using structured interview schedule. A multi-stage sampling technique was used to select 100 mushroom farmers by purposefully selecting ten (10) communities from Three Local Government areas that made up Ikwerre kingdom, namely: Ikwerre, Emuohua, and Obi/Akpor. Data were analysed using descriptive statistics such as mean score, percentage and frequency. The study revealed that a higher number (40\%) of the respondent were between the age bracket of 50-59 years, the majority (65\%) of the respondents were married, 67\% had no formal education, 47\% had 11-15 years harvesting experience and they harvested pleurotus astreatus mushroom (45\%). A higher number (68\%) of the respondents were into mushroom harvesting and trading. Mushroom harvesters (wholesale) sell a basket of mushroom for 1500.00, while the retailers incur a total variable cost (TVC) of $\$ 550.00$ and earn total revenue (TR) of $\$ 1,500.00$, realizing a profit of 950 . The major benefit of mushroom harvesting to rural women was that it serves as a source of income (57\%). Major constraints to harvesting and marketing of mushroom were: non availability (85\%) and religion (13\%). The study recommends that government and extension agents should educate indigenous mushroom harvesters on new techniques of how to grow and cultivate mushrooms to all year round.

Keywords: Indigenous mushroom, harvesting, marketing

\section{Introduction}

The word Mushroom may mean different things to different people and countries. In a broad sense, mushroom is a macro fungus with a distinctive fruiting body, which can be either epigeous or hypogenous and large enough to be seen with naked eye and to be picked by hand (Raphael, 2015). Mushroom belongs to two subdivisions of fungi, vast majority belongs to Basidiomycetes, and a few belong to Ascomycetes. According to 
Creative Commons User License: CC BY-NC-ND

Abstracted by: EBSCOhost, Electronic Journals Service (EJS)

Google Scholar, Journal Seek, Scientific Commons,

Food and Agricultural Organization (FAO), CABI and Scopus
Journal of Agricultural Extension

Vol. 23 (1) January, 2019

ISSN(e): 24086851; ISSN(Print); 1119944X

http://journal.aesonnigeria.org

http://www.ajol.info/index.php/iae

Email: editorinchief@aesonnigeria.org

http://eoi.citefactor.org/10.11226/v23i1

(Raphael, 2015), it is estimated that about 140,000 different species of mushroom exist in the planet; however, only about $10 \%$ are known. He also stated that there are about 2000 species of Mushrooms that are safe for consumption and 700 species are known for possessing some pharmacological properties. Edible mushrooms are attractive because of their flavour, taste, and delicacy. Although many species of edible mushrooms exist in nature, less than 20 species are used as food and only 8 to 10 species are regularly cultivated in significant extent.

Mushrooms offer tremendous applications as they can be used as food and medicines besides their key ecological roles. They are among one of the world's greatest untapped resources of nutrition and palatable food of the future. Due to the high amount of protein found in them, they can be used to bridge the protein malnutrition gap. Edible mushrooms have been widely utilized as human foods for centuries and have been appreciated for texture and flavour as well as some medicinal and tonic attributes (Raphael, 2015). He stated further that mushrooms are considered as healthy food because they are low in calories and fat but rich in proteins and dietary fibers; mushrooms protein contains all the nine essential amino acids required by humans. In addition to their good protein content, mushrooms are a relative good source of nutrients like phosphorus, iron and vitamin, including thiamine, riboflavin, ascorbic acid, ergo sterol, and niacin.

Mushroom harvesting used to be a popular hobby among youths and rural women in rural communities who use it as a source of income. Many edible species have been described and identified in Nigeria. Auricularia auricular is a type of mushroom eaten by many people in rural areas (Raphael, 2015). They are traditionally collected on wet logs on the woods during the rainy season or on log under shades in the forest. Mushrooms are either marketed fresh as soon as harvested or preserved by whatsoever means as quickly as possible. In other to effectively preserve mushroom, they should be kept cold with storage temperature of $0-2^{0} \mathrm{C}$ within five hours of picking or sun-dried, especially in the tropics during the dry season (Simeon and Sadiat, 2012). It is equally advisable to sundry as soon as it was harvested.

The need for mass consumption of mushroom and mushroom delicacies as an alternative source of protein and vitamins has not been well appreciated by majority of our people, even when the market prices of meat and fish have increased enormously. The superstitious beliefs that mushrooms are distasteful and poisonous are mysteries that have overwhelmed the minds of many toward the consumption of mushroom. This is as a result of inability to distinguish edible mushroom from poisonous types thereby not allowing the rural people from knowing the importance of mushroom (Raphael, 2015). The over dependent on natural available mushroom has led to mushroom scarcity and shortage in supply. This is simply because mushrooms are seasonal and edible ones are selective in their natural habitat. Therefore, to solve the problem of mushroom scarcity, mushroom has to be cultivated all year round.

Mushroom is now an accepted food among many households in Ikweree kingdom. It is harvested and marketed by mostly women as women in Ikwerre kingdom go to the forest to harvest edible mushrooms. The common material used to harvest mushroom is the basket. Mushroom harvesting and marketing has become a source of livelihood for some rural women. Information on indigenous use and harvest of mushrooms had been passed orally from one generation to another (Simeon and Sadiat, 2012). It is possible that some of this 
Creative Commons User License: CC BY-NC-ND

Abstracted by: EBSCOhost, Electronic Journals Service (EJS)

Google Scholar, Journal Seek, Scientific Commons,

Food and Agricultural Organization (FAO), CABI and Scopus
Journal of Agricultural Extension

Vol. 23 (1) January, 2019

ISSN(e): 24086851; ISSN(Print); 1119944X

http://journal.aesonnigeria.org

http://www.ajol.info/index.php/iae

Email: editorinchief@aesonnigeria.org

http://eoi.citefactor.org/10.11226/v23i1

undocumented information had been lost. According to them, the women who sell vegetables and mushrooms and elderly people are usually most helpful in supplying information about ethno mycological uses of mushrooms in south west of Nigeria and in Ikwerre kingdom in particular. In essence, the younger generation in Nigeria has little or no knowledge about ethno mycological uses of mushrooms. The purpose of this study was to assess and identify the edible mushrooms in Ikwerre kingdom and Rivers State in general and to determine the economics of mushroom to rural women in the study area. The study specifically:

- $\quad$ described the socio-economic characteristics of mushroom harvesters;

- $\quad$ identified the type of edible mushroom;

- $\quad$ determined the economics of mushroom harvesting and marketing.

- $\quad$ examined the benefits of mushroom to the rural people; and

- $\quad$ ascertain constraints to mushroom usage and cultural harvesting.

\section{Methodology}

Ikwerre kingdom is made up of three local government areas namely lkwerre, Emuohua and Obio/Akpor. The headquarters of Ikwerre is Isiokpo, Emohua is Emohua and Obio/Akpor is Rumuodomaya. The LGAs have large massive land and is endowed with mineral resources. Thus, the major occupation of the people is farming, fishing, and hunting etc. Ikwerre LGA is made up of twelve (12) communities and towns. These communities include: Isiokpo, Omagwa, Omudeme, Elele, Omuanwa, Apani, Ipo, Omerelu, Igwuruta, Ubima, Ozuaha and Aluu. Emohua is made up of five clans namely Rundele, Ibaa, Odegu, Emohua and Elele-Alimini While Obio/Akpor is four clans namely Akpor, Apara, Evo and Obio. Multi stage sampling technique was used to select the respondents in the study area. Firstly, two communities were mushroom harvesting was high were purposively selected from each clan, giving a total of ten communities. Secondly, ten women were systematically selected from each community, giving a total of 100 respondents which was used for the study. Data were collected using structured interview schedule and were analysed using descriptive (percentage, frequency and mean scores) and inferential statistics such as multiple regression and t-test.

\section{Results and Discussion}

\section{Socio-economic characteristics of the respondents}

The socio-economic characteristic of the respondents is shown in Table 1.

Entries in Table1 reveal that a higher proportion (40\%) of the respondents were between the age brackets of $50-59$ years. The mean age is 44.5 years. This indicates that the women involve in mushroom harvesting are middle-aged women; this may be as a result of urban rural migration of the youths, leaving the aged women in the village. However, the mean age of 44.5 years implies that the women involved in mushroom harvesting are active, young, vibrant women who are in their productive stage. This disagrees with Idio and Obinaju (2013) who observed that the majority of mushroom farmers were between 3140 years. The majority (65\%) of the respondent were married. This implies that the women involved in mushroom harvesting are married and have the responsibility of helping their husbands to provide the basic needs of the family. According to Albert and Nne-cosy 
Creative Commons User License: CC BY-NC-ND

Journal of Agricultural Extension

Abstracted by: EBSCOhost, Electronic Journals Servir

Google Scholar, Journal Seek, Scientific Commons,

Food and Agricultural Organization (FAO), CABI and Scopus

http://eoi.citefactor.org/10.11226/v23i1
Vol. 23 (1) January, 2019

ISSN(e): 24086851; ISSN(Print); 1119944X

http://journal.aesonnigeria.org

http://www.ajol.info/index.php/jae

Email: editorinchief@aesonnigeria.org

(2014) marriage makes people to show sense of responsibility towards the family in the area of taking care of the children and meeting family needs. Also, a majority $(67 \%)$ of the respondents had no formal education.

Table 1: Socio-economic characteristics of the respondents

\begin{tabular}{|c|c|c|}
\hline Variables & Percentage $(n=100)$ & Mean \\
\hline \multicolumn{3}{|l|}{ Age (years } \\
\hline $20-29$ & 2.0 & \\
\hline $30-39$ & 18.0 & \\
\hline $40-59$ & 30.0 & 44.5 years \\
\hline $50-59$ & 40.0 & \\
\hline $60-69$ & 10.0 & \\
\hline Total & 100.0 & \\
\hline Female & 100.0 & \\
\hline \multicolumn{3}{|l|}{ Marital status } \\
\hline Single & 10.0 & \\
\hline Married & 65.0 & \\
\hline Separated & 8.0 & \\
\hline Widow & 17.0 & \\
\hline Total & 100.0 & \\
\hline \multicolumn{3}{|l|}{ Household size } \\
\hline $1-4$ & 17.0 & \\
\hline $5-8$ & 50.0 & \\
\hline $9-12$ & 23.0 & 8 persons \\
\hline $13-16$ & 10.0 & \\
\hline Total & 100.0 & \\
\hline \multicolumn{3}{|l|}{ Education } \\
\hline Primary & 20.0 & \\
\hline Secondary & 4.0 & \\
\hline Non-formal & 67.0 & \\
\hline \multirow{2}{*}{\multicolumn{3}{|c|}{ Harvesting experience }} \\
\hline & & \\
\hline $1-5$ & 15.0 & \\
\hline $6-10$ & 28.0 & \\
\hline $11-15$ & 47.0 & 10.5 years \\
\hline $16-20$ & 10.0 & \\
\hline \multirow{2}{*}{\multicolumn{3}{|c|}{ Monthly Income from mushroom harvesting }} \\
\hline & & \\
\hline $5,000-10,000$ & 28.0 & \\
\hline $11,000-15,000$ & 52.0 & $\# 12460.00$ \\
\hline $16,000-20,000$ & 20.0 & \\
\hline Total & 100.0 & \\
\hline \multicolumn{3}{|c|}{ Secondary occupation } \\
\hline Farmer & 73.0 & \\
\hline Petty trader & 14.0 & \\
\hline Public service & 3.0 & \\
\hline Civil service & 2.0 & \\
\hline Herbalist & 8.0 & \\
\hline Total & 100.0 & \\
\hline
\end{tabular}

Source: Field Data, 2017

This implies that women who are involved in mushroom harvesting had low education while some had no education. Illiteracy on the part of the mushroom harvesters could serve as a barrier in getting good knowledge on how to grow mushrooms around them. The mean years of harvesting experience is 19.5years. This indicates that the mushroom harvesters 
Creative Commons User License: CC BY-NC-ND

Abstracted by: EBSCOhost, Electronic Journals Serv

Google Scholar, Journal Seek, Scientific Commons,

Food and Agricultural Organization (FAO), CABI and Scopus
Journal of Agricultural Extension

Vol. 23 (1) January, 2019

ISSN(e): 24086851; ISSN(Print); 1119944X

http://journal.aesonnigeria.org

http://www.ajol.info/index.php/iae

Email: editorinchief@aesonnigeria.org

http://eoi.citefactor.org/10.11226/v23i1 have been long in the business of harvesting and therefore will have enough knowledge of
mushroom harvesting to give a good and accurate account of its marketing and challenges. Albert, Nnodim and Cookey (2013) stated that years of experience help in giving account of events. Greater percentage (52\%) of the respondents in mushroom harvesting earn up to N11,000- $\$ 15,000$ monthly. This implies that mushroom harvesting has high-income rate and therefore it is a good source of income to the women.

\section{Relationship between Socio-economic Characteristics and Mushroom Harvesting}

The linear model showed a positive sign of $R$ square $=0.6021$ and f-ratio of 0.323 at a $p$ value of 0.005 indicating a significant relationship between socio-economic characteristics such as age, sex, marital status, education, household size, years of experience, income and secondary occupation and mushroom harvesting. (Table 2)

\section{Linear}

$Y=6.32+1.23 x_{1}+4.71 x_{2}+1.82 x_{3}+3.00 x_{4}+2.45 x_{5}+7.02 x_{6}+3.34 x_{7}+0.65 x_{8}+0.5309$

$R^{2}=0.6021$

Table 2: Regression of socio-economic characteristics on women involved in mushroom harvesting

\begin{tabular}{llll}
\hline Parameters & Linear & Semi-log & Double-log \\
\hline Multiple R Square $\left(\mathrm{R}^{2}\right)$ & $0.6021^{*}$ & -0.091 & -0.22033 \\
f-ratio & $0.323^{*}$ & -1.766 & -0.4908 \\
P-value of the f. ratio & $0.005^{*}$ & -2.432 & -2.30103 \\
Variables & 0.087 & -0.764 & -1.06048 \\
Intercept & $6.32(1.54)^{*}$ & $-4.03(1.05)^{\mathrm{ns}}$ & $0.80(0.18)^{*}$ \\
Age & $1.23(0.76)^{*}$ & $1.43(0.12)^{*}$ & $0.08(-0.11)$ \\
Sex & $4.71(1.97)^{*}$ & $0.54(2.34)$ & $0.67(0.29)^{\star}$ \\
Marital Status & $1.82(0.22)^{*}$ & $-6.43(-0.32)$ & $0.26(-0.65)$ \\
Household Size & $3.00(1.87)^{*}$ & $9.54(0.76)$ & $0.47(0.27)^{*}$ \\
Education & $2.45(0.03)^{*}$ & $8.40(2.43)^{*}$ & $0.38(-1.52)^{*}$ \\
Harvesting Experience & $7.02(2.76)^{*}$ & $12.23(3.15)^{\star}$ & $0.84(0.44)^{\star}$ \\
Monthly Income & $3.34(1.54)^{*}$ & $1.41(0.21)^{\star}$ & $0.52(0.18)^{*}$ \\
Secondary Occupation & $0.65(1.02)$ & $-1.34(0.65)^{\star}$ & $-0.18(0.01)$ \\
\hline
\end{tabular}

Figures in parentheses are t ratios; * $\mathrm{P} \leq 0.05$. Source: Field survey, 2017

\section{Types of Edible Mushroom in the Study Area}

Table 3 reveals that a higher number (45\%) of the respondents harvest pleurotus astreatus, followed by $30 \%$ of the respondents that harvest Auricularia aricular-judea and $23 \%$ of the respondents harvest pleurotus tuber-regium. The remaining $20 \%$ of the respondents harvest Agaricus bioporus. This implies pleurotus astreatus and auricularia aricular-judea mushrooms were the most harvested types of mushroom. This is probably the most 
Creative Commons User License: CC BY-NC-ND

Journal of Agricultural Extension

Abstracted by: EBSCOhost, Electronic Journals Service (EJS), Vol. 23 (1) January, 2019

Google Scholar, Journal Seek, Scientific Commons,

Food and Agricultural Organization (FAO), CABI and Scopus

http://eoi.citefactor.org/10.11226/v23i1

available mushroom in the study area and probably accepted and eaten by the rural people.

Table 3: Types of edible mushroom in the study area

Variables

Auricularia auricular-Judea

30.0

Pluerotus tuber-regium

Agaricusbiosporus

Pleurotusostreatus
23.0

2.0

45.0

\section{Percentage}

$\%$

Multiple Responses

\section{Economics of Mushroom Harvesting}

Table 4 shows that $68 \%$ of the respondents were involved in harvesting and trading of mushroom while $32 \%$ only harvest mushroom. This disagrees with Onwubuya et al (2015) that observed that mushroom farmers harvest mushroom for household consumption in Abia State.

\section{Table 4: Economics of mushroom marketing}

\begin{tabular}{|c|c|c|}
\hline Economic issues & & Cost \\
\hline $\begin{array}{l}\text { Trade on mushroom } 68 \% \text { (yes) } \\
\text { Wholesale }\end{array}$ & & \\
\hline $\begin{array}{l}\text { Farmer sell a basket of mushroom } \\
\text { Retailers } \\
\text { A. Total variable cost (TVC) }\end{array}$ & - & $A 500.00$ \\
\hline A basket of mushroom & - & A500.00 \\
\hline Labour & - & $\$ 50.00$ \\
\hline A550.00 & & \\
\hline 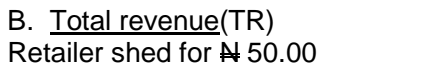 & & \\
\hline From a basket 30 sheds & & $\mathrm{A} 1,500.00$ \\
\hline Profit & - & A950.00 \\
\hline
\end{tabular}

\section{Source: Field Data, 2017}

Table 4 also shows that the mushroom harvesters (wholesale) sell a basket of mushroom for $\$ 500.00$, while the retailers incur a total variable cost (TVC) of $\$ 550.00$ and earn total revenue (TR) $\$ 1,500.00$ from shading mushroom for $\$ 50.00$ into 30 places from a basket. The gross margin is $\$ 950$ which implies that mushroom business or trading is a profitable one and the retailers make more profit than the mushroom harvesters. Idio et al (2013) stated that mushroom business is a profitable venture. 
Creative Commons User License: CC BY-NC-ND

Abstracted by: EBSCOhost, Electronic Journals Service (EJS)

Google Scholar, Journal Seek, Scientific Commons,

Food and Agricultural Organization (FAO), CABI and Scopus
Journal of Agricultural Extension

Vol. 23 (1) January, 2019

ISSN(e): 24086851; ISSN(Print); 1119944X

http://journal.aesonnigeria.org

http://www.ajol.info/index.php/iae

Email: editorinchief@aesonnigeria.org

\section{Benefits of Mushroom to the Rural Women}

Table 5 reveals that more than half $(57 \%)$ of the respondents indicated that the benefit from mushroom harvesting is that it is a source of income. The result indicates that the major benefit of mushroom harvesting is that it is a source of income to the rural women who deals on sale of mushroom and a source of livelihood to the rural women who harvest and sell mushroom. Mushroom is also important in the use of the treatment of various ailments.

Table 5: Benefits of mushroom to the rural women

\begin{tabular}{ll}
\hline Benefits & Percentage \\
\hline Livelihood & 20.0 \\
Employment opportunity & 3.0 \\
Source of income & 57.0 \\
Alternative source of protein & 8.0 \\
Treatment of disease & 12.0 \\
\hline
\end{tabular}

Source: Field survey, 2017

\section{Constraints to Mushroom Usage}

Table 6 shows that majority (85\%) of the respondents indicated that none availability of these mushroom is the major constraints to mushroom harvesters as they are seasonal fungi. While only $2 \%$ of the respondents indicated taste as their reasons for not eating mushroom. This implies that the major constraints to the usage of mushroom in the study area was none availability of the mushroom while taste has little effect on the usage of mushroom. This is contrary to Albert and Tasie (2016) and Albert and Okidim (2017) that taste influence the utilization of most food eaten by people.

Table 6: Constraints to mushroom usage

\begin{tabular}{ll}
\hline Constraints & Percentage \% \\
\hline Belief & 0.0 \\
Religion & 13.0 \\
None availability & 85.0 \\
Taste & 2.0 \\
\hline
\end{tabular}

\section{Source: Field survey, 2017}

\section{Conclusion and Recommendation}

Mushroom harvesting and trading is a profitable venture. Mushroom harvesting has advantages or impact in the life of rural women in the study area as it is a source of income and livelihood to them. However, it has some constraints such non-avalailibity of mushroom in the area and religion. Government should create awareness or educate indigenous mushroom harvesters, about the new techniques on how to grow and cultivate these mushrooms around them in order for it to be available to them all year round. Educate the mushrooms harvesters in the rural communities on the benefit of mushrooms as food and 
Creative Commons User License: CC BY-NC-ND

Abstracted by: EBSCOhost, Electronic Journals Service (EJS), Google Scholar, Journal Seek, Scientific Commons,

Food and Agricultural Organization (FAO), CABI and Scopus

http://eoi.citefactor.org/10.11226/v23i1

as medicine and to make them aware that not all mushrooms are poisonous and distasteful.

\section{References}

Albert, C.O \& Okidim, A.I. (2017). Factors influencing utilization of frozen fish among rural households in Ikwerre Local Government Area of Rivers State. Delta Agriculturists, 9(1), 2431.

Albert, C.O \& Tasie, C.R. (2016). Survey on frozen fish consumption pattern among selected households in Obio/Akpo Local Government Area of Rivers State, Nigeria. Agricultura Agricultural paractice and science journal, 3-4 (99-100), 95-1-2.

Albert, C.O. \& Nne-Cosy, J. (2014). Analysis of family planning programmes among rural households in Ogba/Egbema/Ndoni Local Government Area of Rivers State, Nigeria. Agricultura Agricultural Practice and Science Journal, 1-2(89-90_, 150-163.

Albert, C.O., Nnodim, A.U. \& Cookey, A.T. (2013). Analysis of skills acquisition programme (SAP) on employment opportunities in rural Rivers State. Journal of Research on Humanities and Social Sciences, 3(9), 106-109.

Idio, A.D. \& Obinaju, L.C. (2013) Analysis of edible mushrooms marketing in the Central Senatorial Zone of Cross River State, Nigeria. Journal of Advances in Arts, Social Sciences and Education Research, 3(7), 1-20.

Onwubuya, E.A., Ajani, E.N., Dike, C. \& Nduzokwe, U.N. (2015). Popularization of Mushroom production technologies among small-scale farmers in Abia State, Nigeria. International Journal of Research in Agriculture and Forestry, 2(1), 1-7

Raphael, N.O. (2015). Ethno Study and Usage of Edible and Medicinal Mushrooms in Some Parts of Anambra State, Nigeria.

Simeon, D.Y.A \& Sadiat, F. A. (2012).Socio-economic and cultural factors that affect mushroom production in Southwest Nigeria. Agriculture Tropical ET Subtropical, 45(2), 78-83. 